Article

\title{
Family Home Business in Kibbutz Industry Sustainability
}

\author{
Yaffa Moskovich 1,2 \\ 1 Zefat Academic college, Safed 1320611, Israel; yafam@zefat.ac.il \\ 2 Kibbutz Institute of Cooperative Idea, Haifa University, Haifa 3498838, Israel
}

Received: 4 June 2020; Accepted: 28 June 2020; Published: 3 July 2020

check for updates

\begin{abstract}
This study defines and examines kibbutz industries as an expanded form of family business. It explores the sociological characteristics of this new type of enterprise, extending familial business culture theory innovatively by adding a new category of business to those already described in the relevant literature. The research addressed multiple case studies, using anthropological interviews and document analysis methods to explore three new familial types: 1. Communal Familial Type, Kibbutz industries that are still communal and have retained familial attributes; 2 . Business Communal Familial Type, Kibbutz industries that have undergone privatization, retaining only half the communal cultural features typical of kibbutzim and displaying greater business orientation; 3 . Business Type, Kibbutz industries that have lost their familial attributes or communal cultural features. The first two types maintain kibbutz community and industrial sustainability, while the last can be a threat to kibbutz sustainability.
\end{abstract}

Keywords: family business; kibbutz community; kibbutz industry; sustainability

\section{Introduction}

This study defines and examines kibbutz industries as an expanded form of family business. Family business firms have potential to persevere over time and to contribute to the social responsibility and sustainability of kibbutz industry and kibbutz communities [1,2]. By exploring the unique features of kibbutz industry and the kibbutz community, this study shows how these industries were adapted to changing environmental conditions. The results can shed light on an organization's dependence on its surroundings [3] by demonstrating how the kibbutz community strove for its sustainability through the acceptance of new forms of familial business. This development can supply knowledge to other communities, recommending familial business changes that can help them to overcome difficulties and survive [4-6].

The study examined the sociological characteristics of this new type of enterprise, extending familial business culture theory innovatively by adding a new category of business to those already described in the relevant literature. To date, studies concerning kibbutz industries have accorded little attention to their familial perspective [7-10]. The present study assumes that organizational development in familial business creates cultural changes in the enterprise itself and also generates interaction between it and its community. This adaptation is a key factor in understanding the dynamism in kibbutz community sustainability over more than a hundred years and can explain the significance of the research described hereunder.

The study relates to a different type of family business; it addresses community (kibbutz) members as an extended family and assesses their interaction with their workplace accordingly [11]—an innovative perspective, indeed, because kinship relationships are not necessarily obtained among all kibbutz members. Nevertheless, the kibbutz economy does operate as a single entity with an extended family structure. Although in the past, kibbutz members shared close mutual lives in every aspect as 
family members [1], the Kibbutz community has changed over the years and has adjusted to liberal capitalistic global conditions.

Academic studies of family businesses did not consider communal features to be relevant to this sociological phenomenon [12-14]. Accordingly, the present study will expand on family business behavior and add a new type of familial business style that is relevant to communal and cooperative organizations but has not been accorded adequate treatment in research literature [15-17]. Another innovation of this study is its exploration of family business cultural characteristics and social conditions in kibbutz industry-a topic largely ignored in the research literature that will shed considerable light on this ethnographic phenomenon [10].

The study seeks to define and examine the various types of family business structures applied by kibbutz industries and the sociological characteristics of their familial attributes. It then analyzes the internal and external macroeconomic aspects of the conditions that engendered each such a business type. It concludes with an ethnographic/anthropological description of cultural aspects that shed light on the kibbutz industry "DNA" that developed in this unique communal and cooperative environment. Family business study in kibbutz industry gives us a glance at an ethnography that has been accorded little academic attention to date yet bears a wealth of information about everyday lifestyles, norms and values in a changing communal society [18].

The successful maintenance of family firms is attributed to the adoption of practices that help the company to sustain a vibrant culture and build long-term relationships with its close community. The case study sheds light on the performance of a kibbutz industry that preserved its sustainability over more than 70 years. The kibbutz ethos passed from one generation to its successors through the maintenance of traditional collective values while simultaneously evolving and adapting new characteristics of familial types.

\section{Cultural Attributes of Family Businesses}

\subsection{Kinship Familial Relationship}

Family relationships are changing; some perceive the family as an old, irrelevant structure in our postmodern world. [18]. In the past, anthropologists studied kinship relations in different cultures, but since the 1970s and 1980s, after the development of gender studies and feminism, kinship became less important and has been relegated to the sphere of technological development. Early anthropologists saw kinship relationships as the basis of social and political structure, providing their continuity and sustainability over time $[19,20]$. They were interested in the division of labor in the family and relationships between children and parents, familial succession and heritage. Since then, however, anthropologists have developed further kinship and familial relationship studies that are metaphorical, not limiting themselves to blood connection alone but also including social interaction, drawing analogies from physical bonds to social connections. This familial analogy became more common in organizational life [10]. Contemporary research on relationships is more concerned with local examples, analyzing everyday life for its rituals, rules, celebrations, meals and creative energies.

Family businesses can be identified by mutual experience, history, symbols, stories and pertinence that improve economic success and enhance familial involvement in the firm [21]. Members' self-identification is an essential element of a familial enterprise [14]. Mutual identity links high technical quality standards with sensitivity to customers' needs [22].

A familial business is based on kinship bonds: commercial affairs are conducted by the founders and then handed down to their successors from one generation to the next [5]. Once, family businesses passed from parents to children, but contemporary definitions are changing. In Germany, for example, a family business may have numerous owners/operators, only a few of whom belong to the original nuclear family [6]. New structures affect internal relationships: kinship family members maintain close interaction, while others exhibit more formal relationships, as they would in any other organization 
with its own regulations and hierarchy [23]. Family businesses with outside members tend to resemble formal organizational bureaucracies rather than familial enterprises [17].

Success in family business firms and their expansion did not alter nuclear family control. Founding families usually build in formal mechanisms to manage decisions and supervise company activity and expenses [6]. Diversity is now changing the decision-making process, however, ensuring that more externals are involved, with a more businesslike orientation.

The growth of family businesses has initiated complex structures and several cultural transitions over the years $[5,22]$. Increasing diversity may also cause conflicts between family members and externals [5].

\subsection{Family Business Typology}

One well-known typology concerns the management of the family business, i.e., who dominates company affairs, as defined by [16]:

1. Founder/father: the family firm is centered on the initiatives of this key figure in the firm.

2. Close relatives of the founder, as occurs in the second generation once the founding father bequeaths his position to his children or other relatives.

3. A professional who is not a family member, who manages the open family firm.

Family firms may be classified according to similarity in ownership structure, which may also engender similarities in behavior, activities and financial performance [24].

Other typologies and classifications in family business structure may relate to the extent to which involvement in the business is another typology, ranging from minor involvement effected through Board of Directors supervision, through to intermediate stages in which the firm is handled more autonomously up to extensive involvement, wherein family members hold all management positions and outside influence is marginal [22]. Alternatively, a business may be classified as independent rather than additive when family involvement is highly evident in business activity, policies and decision-making processes [6].

Familial business can be developed by establishing levels of professionalization whose dimensions are discernible according to the adaptation steps taken to cope with environmental changes $[25,26]$, as well as personnel recruitment practices. Some researchers identify a particular familial business type according to its insistence on only hiring family members. Another familial business type hires external candidates for managerial positions if required to improve professionalism [27,28]. Still, other researchers consider professional management and family management to be mutually exclusive [29], while Dekker and colleagues (2012) [30] refer to a business as domestic if it hires only family members and hybrid if it combines family members and external employees (hereinafter: "externals"). Once externals become an integral part of a family business, the entire nature of its business characteristics-its culture and performance-becomes altered [10,24,29].

Other typologies relate to four types of organizational culture [19]: paternalistic, laissez-faire, participative and professional. In the first type, the founding father dominates the business, while laissez-faire culture is more indifferent regarding business activity; the participative type includes family members who are very involved in the business, and the last type involves more externals behaving as professionals rather than exhibiting kinship relationships.

\subsection{Family Business Cultural Features}

Research on family businesses shows that they establish relationships based on altruistic behavior. Family members are committed to helping and being attentive to the needs of their relatives rather than focusing on economic motivation $[16,17]$. All familial cultures reflect commitment, trust and accountability. These principles foster close, informal and open communication that enhances consensus and a positive atmosphere while preventing friction within the enterprise. Mutual responsibility and a 
sense of belonging promote innovation and creativity, reinforcing the powerful sense of togetherness that also has an impact on business performance) $[11,15,31]$.

The familial climate is supportive, engendering lower work stress levels and greater family integrity [32]. Workers enjoy a flexible timetable, allowing them to handle both work demands and personal needs. Managers are more sensitive to their employees' requirements and wellbeing. These convenient working conditions lead to internal solidarity, work enthusiasm and low absence rates [33-35].

A family home business is identifiable according to clan characteristics [36]. The manager is committed to his workers, displaying a paternal attitude towards them. As in other familial businesses, the manager is like a mentor, encouraging and guiding his workers and teaching them to improve work input. Positive clan-like relationships also contribute to innovation, high productivity and business success [36-38]. In the above discussion of family home business culture, clans were described as having the following sociological features: strong identification with the firm, commitment and high solidarity, as manifested in East Asian cooperatives [33-35].

\section{Research Design and Methods}

The study applies qualitative methods, including organizational ethnography, enabling the researcher to penetrate "another form of life" and "capture the richness of local cultural worlds" [11,38] by approaching the organization studied by viewing the world through the eyes of participants and interpreting their cultural concepts accordingly [39]. The key to ethnography is the application of cultural thinking to all that transpires within a given organization [40]. This methodological paradigm was used for the evaluation of the factories' organizational biographies by gaining access to the organizational settings of the five factories and constructing data networks among business familial industries.

\subsection{Data Description and Source}

The selected kibbutz industries produce agricultural tools and accessories, especially for irrigation and cultivation. These factories participated in the study because they mirror the transformation and wide range of changes taking place throughout the kibbutz community and its industries: privatization, mergers, participation with other kibbutz industries and partnerships with private investors. Gaining entry to kibbutz enterprises was difficult, as most such factories did not allow us to conduct the study. Only five allowed us onto the production floor: of these, only T Industries had remained communal, while the remaining four had undergone privatization. Factories T, A, B and $C$ had reached global proportions, with branches all over the world. The most successful was $T$ Industries, that ranked among the top ten kibbutz industries. Factory B had also enjoyed considerable success, while Factories $\mathrm{A}$ and $\mathrm{C}$ had suffered from difficulties and initiated organizational reform to overcome their crises. Factory A had recruited a new CEO, and Factory $\mathrm{C}$ had merged with another kibbutz industry. These steps had helped the industries to overcome their decline. M (Millennium) Industries had suffered crisis and decline and was eventually sold to a private investor.

\subsection{Research Design}

The research investigated the familial characteristics in kibbutz industry and inquired whether other common cultural attributes were evident. The multiple case study method was conducted to learn about each of the cases, compare the similarities and differences among them and examine the typology of familial business types in kibbutz industries. It identifies and reports complex features and attributes of individuals, groups, organizations, social situations and political processes, viewing each as a distinct phenomenon [41,42]. The case study approach is connected directly to the interpretive method, seeking to comprehend the nature of relevant phenomena through feature analysis. It develops a significant typology by determining causality and may be implemented in business administration [43] and in kibbutz industry as well. 
Ethnographic methods were applied to analyze the unique features of familial businesses in kibbutz industries. To address this sociological phenomenon, the qualitative interpretive method proved useful for the evaluation of the shift towards familial attributes. This ethnography analyzed the development of kibbutz industry by focusing on rituals and celebrations and understanding everyday life in kibbutz industries [18].

Research is designed to acknowledge that "what we call our data are really our own constructions of other people's constructions of what they and their compatriots are up to". During the study, the researcher is engaged in all stipulated routines, participating in daily activities, meetings and interactions with community members $[39,40]$. Data analysis attempts to understand the meaning of business life as reflected in documents and newsletters from the organizations researched. The data collected provided information concerning organizational life, including work procedures, as well as the organizational events and ceremonies described in internal documents [44]. The case study concerned the Israeli center/branches only; its findings describe organizational culture at the kibbutz itself and not in the industry's overseas branches.

One hundred ethnographic interviews-a common research procedure [44,45]—-were conducted at all the participating factories between 2012 and 2019 (forty more will be completed by 2020). During the first round of interviews, participants and researchers conducted an open conversation, as in a normal verbal exchange, fostering mutual trust and understanding. To increase the likelihood of relevant information flow, the researcher encouraged participants to speak about their everyday lives, including their familial home culture, which we sought to examine in these ethnographic interviews $[45,46]$.

Participants included a variety of organizational interviewees: current and previous CEOs, current members of the Board of Directors, company Presidents, a Vice President for Operations, numerous department managers (assembly line, finance, human resources, logistics, marketing, styling and production), a delivery coordinator, engineers (one kibbutz member in quality control and an external employee in development), bookkeepers and workers in various departments (computers, information systems, production and sales), secretaries, production line workers and young kibbutz members employed on a short-term basis before commencing military service or higher education, for a total of about a hundred interviews (once data collection was completed). The research was dynamic, changing in accordance with the field data collected.

\subsection{Document Analysis}

To complete the organizational analysis, the study used internal documents, including publications describing organizational events (e.g., celebrations, gatherings and managerial meetings). Documents were selected to seek information about the narrative of familial business types. To analyze unique attributes, the researcher used internal newsletters, constituting a useful source of information about the special events and climate in the organization. Documents were also obtained during the interviews; for example, one employee submitted a printed description of the vision of $\mathrm{T}$ Industries, and another, a report describing its organizational culture. Other factories, such as Factory B, summarized their history through their publications: house organs bearing statements by top management, describing their views, vision and thoughts. Interviews also gave voice to veteran employees, although most information was presented from a managerial point of view. Furthermore, the newsletters provided knowledge about sales, exhibitions and personnel turnover (who was recently hired, who resigned, who retired, etc.).

Certain factories published booklets that summarized their history over several decades, such as Dream and Practice [47] or Sixty Years of T Industries [48]. Other documents, based on speeches and interviews, described managerial policy and perceptions of other factories, including organizational advice from Factory A, as well as internal newsletters from Factories A, B and C and Millennium Industries. These findings helped to forge familial business types and cultural characteristics. 
Once all the documents were obtained, they were classified by topic and then organized into meaningful categories: financial information; job and personnel changes; social events and celebrations; information about workshops, products and exhibitions; and personal interviews. Document analysis contributed information about management's strategic long-range plans, such as addresses by presidents or CEOs, who declared their policies at social events. Some information relevant to the category of "tending to the wellbeing of kibbutz family members" was found in workshop and social event reports, while "convenient working conditions" were revealed in interviews with factory employees. Much information was required to complete our knowledge about the "close, familial atmosphere", especially the type published in reports on interviews, workshops and social events. Financial knowledge was also very important for describing economic conditions relevant to familial business development. Other categories were completed through interviews [18].

\subsection{Data Analysis}

The ethnographic perspective critically examined beliefs that are taken for granted [46]. The study explores the top management's communal perspective and found that these views were accepted by most factory workers. Given the importance of researcher reflexivity in ethnographic research, the researcher makes a special attempt to understand the importance of the adjoining kibbutz community from the individual perspectives of various participants. The factories' cultural values and beliefs were expressed by all employees, labor and management alike, who act as representatives of their respective organizations. This process is an important validating criterion for ethnographic research [48].

The analytical process interpreted cultural topics [49] and subsequently applied the resulting conclusions in the evaluation of interviews and documents. This method assigned each portion of data to a relevant category, enabling the consideration of all such information when constructing an organizational narrative. Ongoing comparison was carried out in several stages, as detailed below.

The study applied thematic analysis conforming with grounded theory [50]), as employed in previous kibbutz industry studies. The process consists of encoding qualitative information to enhance our understanding of research phenomena. The categories were familial features-such as hiring several kibbutz workers that belong to the same family, nurturing and promoting kibbutz members over externals, forming strategic long-range plans and tending to the wellbeing of kibbutz family members. The final stages of the research constructed and defined the familial business culture in kibbutz industry by assembling a typology suiting the socioeconomic conditions prevailing therein [44].

\section{Findings}

\subsection{Kibbutz Industry}

Today, more than $75 \%$ of kibbutzim are officially called renewed kibbutzim, having undergone a privatization process. Kibbutz communities experienced a massive crisis in the 1980s and 1990s, forcing the communities to introduce organizational changes that affected their lifestyles and economic enterprises. Contemporary kibbutz members live in communities that are no longer democratic and equal. In the past, decisions were made by kibbutz committees, with all members participating in the decision-making process. Kibbutzim decided to separate economic enterprises from the communities; each industry is now handled by its management, without requiring the entire community's involvement. Managers enjoy independence and need only report revenue to the community once a year. At many kibbutzim, the community still maintains nominal ownership of the industry, but the plant is run by professionals. This change was introduced after kibbutz businesses had been handled poorly by kibbutz members who lacked the requisite professional knowledge and experience [1,10].

Another change introduced was the employment of outside professionals. Before privatization, the community preferred hiring kibbutz members only, but now, many kibbutz industries seek more qualified and better trained professional employees [8]. These changes and others led to the emergence 
of a ranked hierarchy in kibbutz industries [51] (. Socialistic ideology concerning equity and democracy became more individualistic and liberal, affecting kibbutz industries accordingly. Today's kibbutz factories are managed in a centralized manner by a small group of people. Wages also became differential throughout the kibbutz community. Kibbutz members may now work outside their kibbutzim, live a more capitalistic lifestyle and maintain personal assets $[1,2,10]$.

\subsection{Brief History of Researched Kibbutz Industries}

\subsubsection{Factory A}

The factory was established in 1947 by Holocaust survivors. Initially, it manufactured plastic items for office use and document storage, as well as plastic pipes for agriculture. At first, the factory succeeded financially, providing a means of livelihood for its employees, most of whom were kibbutz members [8]. When the global economic crisis of 2006 affected the factory adversely, the kibbutz decided to recruit an outside $\mathrm{CEO}$ - a member of another kibbutz who had gained experience at other kibbutz enterprises. The new CEO introduced massive changes in production lines. The factory stopped producing plastic equipment, focusing instead on the new gray water technology. The new CEO also made some personnel changes, dismissing old kibbutz members in favor of new, younger manpower. His ideas centered on innovation, including the establishment of a creativity team to develop new applications for pipes adapted to handle gray water. This organizational change helped the factory overcome the crisis but caused friction between veteran employees and the new CEO. The plant has since been expanded, including several new overseas branches [52-57].

\subsubsection{Factory B}

Factory B began as a small workshop, established in 1965 to help the kibbutz overcome its economic difficulties. Its chief products were timer-controlled water faucets and valves for agricultural and home use. The plant's innovative water valves soon generated great interest and booming sales. Production expanded to keep pace with demand. Factory B continued to grow as it entered its second decade and began manufacturing various types of faucets, as well as valves for construction and swimming pools. Meanwhile, managers set their sights on overseas markets to expand company activities. The enterprise became global and opened some branches abroad, offering seminars to teach overseas managers how to manufacture the new products. Factory B internalized high-quality European and American standards, explaining its ability to reach new markets. Today, it has 180 employees, both kibbutz members and externals [58-65]. Its production center is situated at the parent kibbutz, whose members are actively involved in its business life [8].

\subsubsection{Millennium (Factory M)}

This enterprise, established in 1979 to produce magnets for various purposes, was initially intended to provide work for kibbutz members. At first, its 20 employees were drawn entirely from the community as planned. By the 1990s, however, the personnel complement had increased to 80 persons, some of them externals, although all the managers were kibbutz members, including several who did not know how to operate a commercial enterprise. The kibbutz also maintained socialistic values that were incompatible with the competitive business environment. Unqualified managers and poor decisions caused the factory to lose money and eventually collapse economically. The factory had difficulties competing with the Chinese and halted production in 2003. The kibbutz decided to sell the factory to a private investor, who now owns $74 \%$ of its shares, with the remainder still held by the kibbutz. After downsizing, the factory employed only ten outside workers. The production line was moved to China, and the Israeli enterprise is responsible for design and sales only [66-71]. 


\subsubsection{T Industries}

Set up in 1950, when Kibbutz T sought employment for elderly and handicapped persons, this enterprise began as a small workshop that produced plastic products. Once a roller press was acquired, it began manufacturing housewares. The factory then obtained more presses and continued to produce items such as toilet seats, plastic lamps and plastic flight suits. Injection molding technology was introduced in the 1960s, so that the factory could continue to expand its product line and include additional items-helmets, for example. In 1967, it set up a new line and began manufacturing plastic ropes for agriculture. One major turning point in factory development was its partnership with John Deere, a world-renowned giant in the production of agricultural vehicles and mechanical devices, that agreed to manufacture plastic ropes for its tractors at $T$ Industries. The company now has four branches in Israel: one at Kibbutz T; another at its kibbutz partner, Kibbutz G; and two others that have no connection to kibbutz communities. The latter two sites hire local urban personnel but are managed by two kibbutz residents. T Industries has 1400 employees in Israel and abroad; $40 \%$ of the employees at the T Industries factory itself, excluding overseas facilities, are kibbutz members, and $60 \%$, hired personnel; of the total staff, $50 \%$ work in Israel and the remainder, elsewhere [48].

\subsubsection{Factory $\mathrm{C}$}

Factory C was founded in 1962as a small workshop producing water filters and plastic irrigation equipment. Over the years, it developed more than 2000 items for agricultural use. The global economic crisis during 2006 affected the factory badly, leading the kibbutz to enter into a partnership with another kibbutz industry that produced the same kind of water filters. The merger, which cost Factory C 10 million EUR, left the kibbutz with only $53 \%$ of its shares; $23 \%$ were owned by a private company, and the remainder, by two other kibbutzim [72]. The merger helped the factory to recover and register profits of more than 73 million USD, having obtained major contracts throughout the world.

The factory's large investment in the merger led to the introduction of certain efficiency measures, such as downsizing and employee dismissal. The company's internal newsletter wrote that the injection department was replaced [73] and many veteran workers were fired and replaced by new employees from both kibbutzim [72]. This metamorphosis aroused considerable tension among kibbutz member personnel. At present, the plant is managed by a professional CEO from another kibbutz who had served previously as the CEO of T Industries.

\subsection{Familial Features}

The familial aspect of kibbutz industry management is reflected in staff's dedication to cooperative and communal ideals. Managers tend to the needs of their kibbutz-dwelling employees and treat them as family. Kibbutz industries prefer hiring community members over externals-a feature central to all the kibbutz factories studied. All the features below support familial cultural norms in the kibbutz community:

\subsubsection{Hiring Kibbutz Members over Externals}

Kibbutz policy is very clear: factories were established to provide a means of livelihood for kibbutz members. At most such kibbutzim, managerial positions are reserved for members. When no qualified candidate can be found within the community, an outside employee is hired [2]. This norm is common to all kibbutz industries. Furthermore, as an assembly manager from Factory B indicated, "Locals are familiar with kibbutz DNA and we prefer them over externals. Our people are devoted to us and we can trust them in the valve department.".

The HR manager at Factory A echoed this statement of policy: "Here, when a member does not find work, he becomes a burden on the kibbutz social system. But when the industry hires an unqualified worker, it causes tension in the factory, because it affects production adversely." Another engineer 
stated: "Community policy calls for keeping kibbutz workers, but sometimes it is very difficult and you need to fire them, even if the kibbutz community objects.".

The CEO of Factory C said that his enterprise's policy is to prevent firing kibbutz members: "In some cases, an employee may be transferred from one department to another, but he still keeps his job." Finding alternative employment for problematic workers is a solution common to several kibbutz factories, because kibbutz communities provide economic insurance even after the privatization process.

\subsubsection{Kibbutz Family Members Working at the Same Plant}

The Factory B CEO declared: “We hire employees' relatives. My daughter started working as a human resources manager after she completed her education in organizational studies.". At all five kibbutz industries studied, employees have close relatives working at the same factory. At T Industries (not a privatized industry), for example, the former CEO's daughter-in-law is the HR manager and his son is the marketing manager. At another kibbutz industry, the former CEO hired his wife as senior secretary. Other factories also have several employees from the same family, although they do not work in the same department.

\subsubsection{Promoting Kibbutz Members over Externals}

This aspect of the familial narrative is common to most of the industries studied. Lower-level managers gradually familiarized themselves with the company's special atmosphere so they could fit in and succeed at their jobs. The CEO used the "kibbutz DNA" metaphor, explaining that you can only understand the kibbutz community if you are a part of it. Externals cannot really gain a sense of kibbutz life. This is why it is better to hire a kibbutz member rather than an external. The CEO recalled that he worked at the same plant for a long time, beginning in a junior position and advancing to his current job. Other kibbutz members also held several successive jobs, growing into the plant naturally as an integral part of the kibbutz industry. This norm was especially prevalent at Factory A and at $\mathrm{T}$ Industries, both of which instituted policies that provide promotion opportunities for good workers. At $\mathrm{T}$ industries. Many top managers began their careers in junior positions, just as the current CEO did when he served as the marketing department manager before assuming his present position. Norms were different at Millennium Industries, where CEOs rose to their position according to their popularity among kibbutz members rather than their job qualifications. This practice was changed in 2006, however, when the economic situation led its parent organization, Kibbutz Yahalom, nominating a professional CEO. As the fourth CEO (2000-2003) mentioned: "You need to understand the market. It is not enough to be popular among kibbutz members. We need to institute higher standards for CEO nomination.".

At times, this policy is criticized by kibbutz employees, as an engineer at Factory $\mathrm{C}$ remarked: "Kibbutz industry need to change its old perception and to fire unqualified workers". Others voiced similar opinions, but preferred that no action be taken. This norm was common to most of the case studies (not Millennium Industries). Policymakers claimed that one needs to nurture and care for family members first. Kibbutz industries will only seek outside employees when they cannot find kibbutz members suitable for managerial positions. This restriction was relaxed in Factory A after the nomination of a new $\mathrm{CEO}$; his policy called for finding the right people for the right position, leading to the hiring of numerous externals for managerial positions.

\subsubsection{Management's Strategic Long-Range Plans}

Socialistic ideas molded the perceptions of the industries' founders, as displayed in the collective concern that is not only avowed declaratively but also manifested as practical action. The most distinctive familial feature of this outlook was the sense of collective responsibility for workers and the surrounding community that most factories expressed. The management's strategic long-range plans mandate the maintenance of the industry as a source of livelihood for kibbutz family members. 
The CEO of Factory B described the prevailing point of view at his enterprise: "Another kibbutz sold its factory, Sadot (pseudonym). I believe that here, at Factory B, the directors are looking ahead to the future.". The CEO provided examples of other kibbutz factories that were sold for profit. At some kibbutzim, however, the factory is perceived as central to the community. This policy is common to both privatized industries, such as Factories $\mathrm{A}$ and $\mathrm{C}$, and those that have remained communal, such as T Industries (see below). The CEOs of all these enterprises expressed their interest in keeping the factory in the long run, refusing to sell it even for considerable profit. The management's primary concern was to provide a means of support to the members of their respective communities $[64,65]$.

\subsubsection{Tending to the Wellbeing of Kibbutz Family Members}

Collective concerns are also realized through hiring elderly kibbutz members for simple jobs in the housewares department at $\mathrm{T}$ Industries, primarily for the purposes of providing them with a social framework suiting their age group. A housewares production manager mentioned that her department is hiring 25 retired elderly members. Her description is like that of a sensitive geriatric social worker:

"They work part time, not full time. One of our industry's goals is to provide work for elderly people. We need to maintain balance between social and economic objectives and adapt work to suit elderly persons. Some like to work alone, while others prefer working in groups. We assign easy jobs to the old-timers, such as putting instruments back in their places or registering and placing labels on products. I phone older employees who are absent, especially if they live alone. If one of them is ill, we arrange visits. Sometimes I maintain contact with families. If their state of mind deteriorates and they become confused, we handle dismissal very delicately."

Another collective concern is reflected in factory policy concerning temporary kibbutz workers on sabbatical from their respective kibbutzim. This situation is typical of many kibbutz factories that hire young kibbutz members for short periods of time just after they complete their military service; they are called bambahim (Hebrew acronym for "kibbutz members on leave"). At Factory A, where they work on the production line, the housewares production manager said: "They see an opportunity and seize it. Some go on to become factory managers.". One young worker remarked that he had been employed at the factory for 13 months, giving him a chance to work together with other young members: "It's a nice place to work, with convenient, flexible hours.". Nevertheless, hiring young and temporary workers can cause conflicts and problems on the production line. Sometimes, veteran employees are dissatisfied with the constant change that the temporary workers undergo. The Israeli site manager at $\mathrm{T}$ Industries noted: "It does not benefit production and even arouses conflict with veteran employees. We hire temps for their social contribution.". A laboratory manager added that the factory is interested in investing in long-term workers, not temps. Factory jobs give young kibbutz members an opportunity to save money, while the factory perceives them as potential permanent employees. Problems occur on the production line because the young people are not trained and experienced and make lots of mistakes at work: "You have the advantage of nurturing gifted workers and offering them managerial positions.".

Factory A helps its kibbutz workers to overcome difficulties, while their workmates tend to their wellbeing. For example, they may help divorced colleagues to find new accommodation, bring them furniture from kibbutz storage, participate in transporting belongings and support them during difficult times.

\subsubsection{Convenient Working Conditions}

All the participants emphasized the homey and family-like atmosphere at their factories. Workers at the three privatized industries ( $\mathrm{A}, \mathrm{C}$ and $\mathrm{M}$ ) spoke of convenient nice environments and said that the managers were sensitive to their workers will. At Factory $C$, one of the workers said:

"Before the merger, work conditions were more convenient. We lived near the factory, increasing the sense of closeness and belonging.". A Factory B employee added: "Formerly, employees could combine work demands with personal matters. If my child were ill, I could go to him and take care of 
him.". Regulations were relaxed, and time clocks were not used, fostering a calm environment with considerable individual freedom and control over personal schedules and other work issues.

The factories that suffered from economic decline (A, C and M), however, had to introduce outside CEOs. After this managerial change, some workers at the three factories were moved from one department to another or from one site to another, arousing numerous complaints against the new management. Factory B arranged annual meetings at which workers could express their thoughts and suggest ways of improving work procedures. T Industries employees also gave voice to their feelings. Their workplace provided them with an opportunity to learn and to develop professionally and personally. Both factories encouraged on-the-job training for their employees, thereby increasing their sense of satisfaction.

\subsubsection{Egalitarian Relationship in Kibbutz Industry}

After privatization, most factories maintained less egalitarian practices towards their workers. Equal status was more common in the early days of the factories. As several participants noted, however, egalitarianism remained central at Factory B. One employee expressed his feelings by noting: "The workers love the factory. It's like their second home.". The kibbutz communal atmosphere at Factory B differed from the prevailing environment at most other factories, where managers did not maintain formal relationships with their workers. The close familial atmosphere fostered friendly ties; as one manager stated, "The hierarchy here was not sacred and social distance was not maintained.". These close relationships caused difficulties among managers, who were recruited from outside the kibbutz. They tried to adjust to the special climate but finally left the factories. Although they were highly qualified managers, the informal relationships disturbed them.

Workers had an open door to the management. They could share their ideas with managers. If they were critical, they could express their views without fear. This special relationship is clearly understandable because they lived together in the same community and met at social events. Firing a kibbutz member was very difficult and was not accepted easily by the community. One human resource manager said: "The kibbutz democratic and egalitarian style is continuing. Although the factory grew in size, it is still familial in nature.".

$\mathrm{T}$ Industries kept up the kind of teamwork that embodies equal relationships among workers and managers. As one former CEO said, "We allow all employees to express their opinions and explain their views. At our weekly review, we examine work planned for the coming week and suggest ideas for improvement.". Kibbutz ideals were based on teamwork, and the plant was characterized by egalitarian relations since its establishment; as an HR employee noted, "We believe in teamwork. We expect every worker to be able to express himself without fear.". A purchasing manager added that at T Industries, teamwork is sacred and highly beneficial. Many teams consist of different types of workers from a variety of geographic locations, each with his or her own unique approach. Teamwork has since undergone certain changes. A former HR manager acknowledged that the egalitarian authority rubric may have originated in the kibbutz style of socialism at T Industries but insisted that the factory manager does require more authority than other employees: "It was a managerial error to give the manager no authority, even though this structure was characteristic of cooperative kibbutzim.". $\mathrm{T}$ Industries, she added, has a well-defined chain of command, noting that inflexible insistence on the democratic process could halt work and render the factory unable to proceed. Her observations reflect a certain change in the implementation of cooperative ideas and procedures.

At Factory A, employees lost their sense of equality after privatization. Kibbutz members working in production and clerical jobs wanted to restore the old collective norms of relationships with management as they had been in the past: equality, fairness and mutual responsibility. A veteran worker claimed that managers had wasted kibbutz funds on their own needs at the expense of workers and factory owners. Another employee criticized the lack of equality among the stratified groups that emerged during the tenure of the new general manager. On the one hand, the ordinary workers earned a modest wage, but on the other, they believed that the factory was illogically wasting funds. 
For example, they thought it was absurd that some of the new managers had cars even though they were kibbutz members and walked to the factory every day. In those cases, the beneficiaries were the managers' wives, who used the company cars even though they did not work for the factory.

At the Millennium plant, equal relationships were more common during the formative stages of factory establishment, but once the company began experiencing financial problems, relations became more formal in nature. The founders wanted to create a new world without stratification. One of the veterans said: "We spent our time together. We ate together without any separation. This work environment gave us a sense of one united family.".

Equality at Factories B, A and C was expressed in the dress code-simple workers, managers and staff employees all dressed in the same manner-and their salaries and personal budgets were equal; as mentioned by a Factory $\mathrm{C}$ manager, "This was a different time. Today, you can observe the difference in dress code. Blue collar workers dress differently from staff workers; you can identify them by their appearance.".

This financial equality became irrelevant after kibbutz plants merged with other enterprises and the resulting industry became hierarchic. The distance between laborers and their supervisors widened; as one veteran employee stated, "Everything is decided by top management without involving the production line workers as they did in the past.".

\subsubsection{Close and Familial Atmosphere}

This narrative was central for most of the factories studied, at which employees display a high sense of commitment, identification and collective responsibility. A graphics department employee at $\mathrm{T}$ Industries added that kibbutz industries provide a familial atmosphere; their managers are highly professional and strongly committed to the organization.

This familial attitude was common at Factory C. Before the merger, the plant was small and intimate. Workers knew each other and maintained primary relationships. The merger destroyed the familial atmosphere. For example, production workers were informed that they could no longer listen to music or chat with their coworkers while on the job. In another case, the Factory A CEO, a kibbutz member, did not fire elderly kibbutz workers, nor did he permit institution of a mandatory retirement age. In 2008, the new CEO insisted on an official retirement age, leading to the dismissal of many elderly kibbutz members. His new regulation adversely affected the familial atmosphere. Retired workers were bitter and complained to the kibbutz management. The external CEO also cut kibbutz workers' benefits and reduced their salaries, leading to much resentment among kibbutz members, but he retained a free hand and the kibbutz management's backing [51].

The familial attitude was common at Millennium Industries before the factory was sold, when the kibbutz community still ran the enterprise. When the factory was established, kibbutz workers invested long hours. Each member felt he or she was contributing to communal wellbeing; as a CEO said, "They shared everything. They ate and celebrated together. If a member had a private celebration, all employees participated and celebrated with them. Kibbutz members brought the food and drinks and the feeling was great!". He added:" The boundaries became blurred and relationships mingled.". However, when the factory suffered decline, it was sold to a private investor and lost its familial attributes. The new owner fired most of the kibbutz workers, and the factory ceased producing magnets. The enterprise now serves only as a marketing facility, as the entire production line was moved to China [71].

Familial feelings were experienced in the factories in the same way: One veteran Factory A employee said: "we liked the informal relationships. We were like brothers sharing everything together, but after the new CEO was appointed, relations became distanced and formal.". A Factory C employee added: "In the past, before the merger, I knew all the workers. They were my friends. But now the factory has grown and taken on many new workers. I don't recognize them and I am feeling very strange. Today managers forbid us to talk with other workers during our shifts. I can't continue this 
way.". Some of the workers at Factory C complained that after the merger, they needed to move to a more distant workplace because the new working conditions decreased their familial feelings.

At $\mathrm{T}$ Industries, a veteran technician said that once, information was more transparent and workers were involved in decision-making. Today, however, now that the industry has expanded and become global, there is less democracy and the management takes on all the leadership functions. He and other veterans long for the close familial atmosphere that prevailed previously. They said that, in the past, it was more common to spread information about new projects, with managers and workers sharing detailed information, encouraging them to progress and evolve professionally. Information is still shared by email or during coffee forums (open to all workers) at which the CEO and marketing manager report about sale and operation news. The housewares manager added that no one reports to workers after management meetings take place as was done in the past. The engineer summarized the radical changes, saying that most of the kibbutz community today is not involved and does not know what is going on. Once, information was transparent, but today, managerial decisions remain unknown. He said: "I notice an organizational culture of concealing information and keeping it under wraps. The management does not want to share information.". He mentioned that during the 1970s and 1980s, decisions were made by workers' committees, but these are totally non-existent today. In the past, managers shared decisions with other departments, but this happens no longer. Today, workers are exposed to limited information that is connected directly with their work only. He complained: "Nobody explains what is going on. The management hides information because they don't want any interference. Once a year, the CEO publishes his achievements and his new plans for the coming year. Kibbutz members are not interested because the bonus increases from year to year.".

This was not the case at Factory B, which displayed numerous features of a familial atmosphere; as described by one of the plant's secretaries, "Although an outsourced cleaning crew came in at night, employees in Factory B left them with no dirt or messes after a day's work.". A production line worker added: "The women brought their own cookies and cleaned the room if it was dirty.".

Moreover, the management invested in numerous social events to nurture a positive atmosphere, thereby increasing organizational solidarity at Factory B and at $\mathrm{T}$ Industries. These events were described in internal newsletters: When a new worker joined the factory, they printed information about his or her past experience. If an employee retired, management and labor wrote about his or her contribution to the factory. When workers had birthdays, the management congratulated them, and so on [58-63].

\subsubsection{Summary of Research Findings}

Familial cultural features in a kibbutz industry reflect the transition from a socialistic to a capitalistic ethos in the kibbutz community. We note the hybrid structure [66] that was based on socialistic norms but also assimilated certain characteristics of capitalism. The familial communal features intensified solidarity and a sense of belonging among kibbutz members. These norms maintained conformism with a collective ethos and reinforced the sustainability of the kibbutz community in an era of globalism and capitalism in Israeli society [20,70]. At the same time, however, others were willing to make the factories more professional by hiring externals for junior and senior duties (managers). The change in this norm reflects the transformation of the kibbutz community and of kibbutz industries that became more professional and improved quality standards; the outcome of this process is a new form of familial type that maintains the sustainability of the factories and the kibbutz community as well $[3,4]$.

\section{Discussion}

The development of new familial types in kibbutz industry can be instructive regarding transition in the kibbutz movement, which was founded by pioneers with revolutionary ideas of strong, collective, communal life resembling that of a homogeneous family. Such attributes were relevant to the first fifty years since the concept was launched until the major economic crisis of the 1970s [2]. The new measures instituted by kibbutzim to overcome their difficulties gave rise to innovative forms of kibbutz 
communities in which strong familial interaction was weakened by privatization [3]. Some kibbutzim stayed communal, but more than $80 \%$ were privatized [22]. The renewed kibbutz community adopted a more liberal and individualistic lifestyle [74] that can accept the emergence of new familial business types.

This familial business development can shed light on the meaning of family from an anthropological perspective. In the early days, relationships at the kibbutz community more closely resembled those of kinship bond families [7]. The first avant-garde settlers shared common strong communal ideas, forging them into a united familial group [74]. During the succession from the formative generation to the next [22], kinship was released from its communal context once privatization began to take place. Familial attributes and bonds became more metaphorical than biological or physical in the kibbutz community and industry. This transition continued to the present type, which has lost both real and metaphoric kinship bonds [18].

Table 1 displays three types of familial culture: Factory B and T Industries are of the communal familial type, at the highest level of familial attributes in business. This observation may be understood according to the socialistic communal traits of nurturing collective responsibility and behaving altruistically $[47,65]$. This business type includes a strong sense of identity and mutual experience and family ties [14,21]. Owners of communal familial enterprises (all kibbutz members) participate in control and management [13] and are highly involved in policy and design [17]. This family business type developed out of the founder-centered family firms established by kibbutz veterans. Each such enterprise is managed by close relatives of the founders, their successors and other kibbutz members who maintain business sustainability [4-6].

The second type of familial kibbutz industry, business communal familial, is exemplified by Factories A and C. In recent years, family firms have become more open, with professional externals serving as managers (particularly after privatization). Kibbutz industries were established by several families with a clan-like structure embodying complex kinship and tribal connections. This type is managed by kibbutz members and professional managers from other kibbutzim or from the private sector, with the sense of belonging and participation in management retained $[6,11,17,21]$. The change is reflected in the decline of the close familial atmosphere, inequality in employee-manager relationships and less satisfactory working conditions. As in the communal familial type, commitment to the community was accorded only marginal significance [11,14,15,17].

The last type is less familial and is referred to accordingly as the business type. In such cases, the factory is managed by private investors and all communal attributes vanish. This type indicates that communal life can be in danger when an enterprise disconnects itself from the community and thereby threatens the latter's sustainability.

Categorizing businesses according to family business type differs from the application of all other typologies, as it focuses on cooperative familial business features $[16,17,24]$, addressing enterprises as extended family businesses of a type that has not been examined in the literature. To date, few studies have taken communal narratives into account when examining family business types [8-10]. The proposed typology is also the first to address the intensity of cooperative characteristics. The most recent typologies were concerned with the extent of familial managerial involvement [4-6,11] but did not address the presence of communal familial features. The cultural typology presented in this study does not categorize businesses as either paternalistic, laissez-faire, participative or professional [21] but rather proposes a new list of characteristics as discovered in this study (Table 1). It provides an anthropological perspective on Israeli kibbutz industry, examining such features as the benefits of an egalitarian attitude towards all workers, nurturing kibbutz members towards the assumption of managerial positions and preferring kibbutz workers over externals. While all these features are also relevant to communal familial business types, the new type, taking previous research into account, addresses issues such as long-term family relationships, commitment, trust, altruism and powerful identification with and commitment to the family business firm. Type 3 companies foster creativity, professionalism and innovation among employees and improve group communication [31-34], professionalism and innovation [4,6,15,22,30]. 
Table 1. Summary of familial features.

\begin{tabular}{|c|c|c|c|c|c|}
\hline Feature & Factory A & Factory B & Factory C & Millennium & $\mathrm{T}$ Industries \\
\hline Hiring kibbutz members over externals & Maintained & Maintained & Maintained & Not relevant & Maintained \\
\hline Kibbutz family members working at the plant & Halted & Halted & Halted & Vanished & Halted \\
\hline Promoting kibbutz members over externals & Lessened & Maintained & Maintained & Not relevant & Maintained \\
\hline Management's strategic long-range plans & Halted & Halted & Halted & Not relevant & Halted \\
\hline $\begin{array}{l}\text { Tending to the wellbeing of kibbutz family } \\
\text { members }\end{array}$ & $\begin{array}{l}\text { Hiring young } \\
\text { kibbutz members }\end{array}$ & $\begin{array}{l}\text { Hiring young } \\
\text { kibbutz members }\end{array}$ & $\begin{array}{l}\text { Hiring young } \\
\text { kibbutz members }\end{array}$ & Vanished & $\begin{array}{l}\text { Hiring young kibbutz } \\
\text { members; opening a special } \\
\text { dept. for elderly people }\end{array}$ \\
\hline Convenient working conditions & Lessened after 2008 & Maintained & Lessened & Vanished & Maintained \\
\hline Egalitarian relationship in kibbutz industry & Lessened & Maintained & Lessened & Vanished & Maintained \\
\hline Close, familial atmosphere & Lessened & Maintained & Lessened & Vanished & Maintained \\
\hline
\end{tabular}


The findings display complicated familial features. A kibbutz industry may be addressed as an extended family concerned for the wellbeing of its members. The industry expects its employees to maintain kinship relations and promotes managers according to their familial affiliation. Many are blood relations of other workers at the same plant. Bonding among kibbutz members is strong and highly committed to collective benefit. Managers are obliged to stay at the factory for an extended period of time, and rank and file employees perceive their workplace as part of their private property. They nurture a productive work environment and invest time and effort in ensuring the success of their mutual asset. This type of business resembles the clan type because of its familial atmosphere and concern for healthy environmental conditions at work [36,37], although such characteristics are more common in communal familial enterprises.

The organizational development represented by the proposed typology may be understood according to its sociological background (Table 2). Privatization exerted a major effect on the familial business type, separating plants from their affiliated communities [1,2,74]. At some factories, the familial atmosphere was weakened by privatization and organizational decline and replaced with a climate stressing professionalism and high standards of quality. Privatization caused the collapse of egalitarian ideology and the abolition of democracy at work. It diminished the familial atmosphere, as evidenced by most of the plants studied (only Factory B is an exception). T Industries remained communal, however, as reflected in the high level of familial attributes.

Table 2. Organizational situation at participating factories.

\begin{tabular}{ccccc}
\hline Economic Status & $\begin{array}{c}\text { Top Management: } \\
\text { Kibbutz Members, } \\
\text { Externals, Mixed }\end{array}$ & $\begin{array}{c}\text { Ownership: } \\
\text { Private, Mixed or } \\
\text { Cooperative }\end{array}$ & $\begin{array}{c}\text { Underwent } \\
\text { Privatization }\end{array}$ & Factory \\
\hline $\begin{array}{c}\text { Organizational decline in 2008 } \\
\text { (overcame crisis) }\end{array}$ & $\begin{array}{c}\text { External (from } \\
\text { another kibbutz) }\end{array}$ & Cooperative & Yes & $\mathrm{A}$ \\
$\begin{array}{c}\text { Successful, profitable factory } \\
\text { Kevere organizational decline; } \\
\text { sold to private investor }\end{array}$ & Private & Cooperative & Yes & $\mathrm{B}$ \\
$\begin{array}{c}\text { Successful, profitable factory } \\
\text { Organizational crisis before }\end{array}$ & Kibbutz members & Pooperative & No & $\mathrm{M}$ \\
2010, merger (overcome crisis) & Mixed & Mixed & Yes & $\mathrm{C}$ \\
\hline
\end{tabular}

Another factor is ownership: Kibbutz ownership supports the development of a familial culture, whereas the selling of industries to private investors tends to reduce it. Communal ownership nurtures familial business features, while private ownership eliminates them because the owners are more interested in profits than in comfortable working conditions at Millennium Industries, for example. Even when ownership is mixed, as in the case of Factory C, familial characteristics are diminished. Finally, the issue of who runs the factory also had an impact on familial aspects. Owner management empowers familial bonds (T Industries and Factory B) because the managers maintain tribal communal connections, but when a factory is managed by externals, the familial atmosphere is weakened (Factories A and C; Millennium Industries), because they do not share communal responsibility but rather concentrate on commercial success.

Kinship relationships are criticized by some kibbutz members, who perceive tribal connections as detrimental to industrial achievement [30]. Familial closeness can be a burden on the community, considering the economic and social conditions required to maintain familial business culture-a policy that this study links with economic prosperity (Figure 1). Factories suffering financial difficulties and decline become less familial and more formal and hierarchical-a result of the drastic measures that the managers of these factories (A, C and Millennium Industries in our case) have to introduce to overcome the economic crisis [51]. The opposite effect was observed at T Industries and Factory B, where sound economic conditions reinforced a familial business type. When an enterprise is successful, 
it has enough money to invest in its workers, enhancing their satisfaction, commitment and solidarity by providing them with good working conditions [11-15].

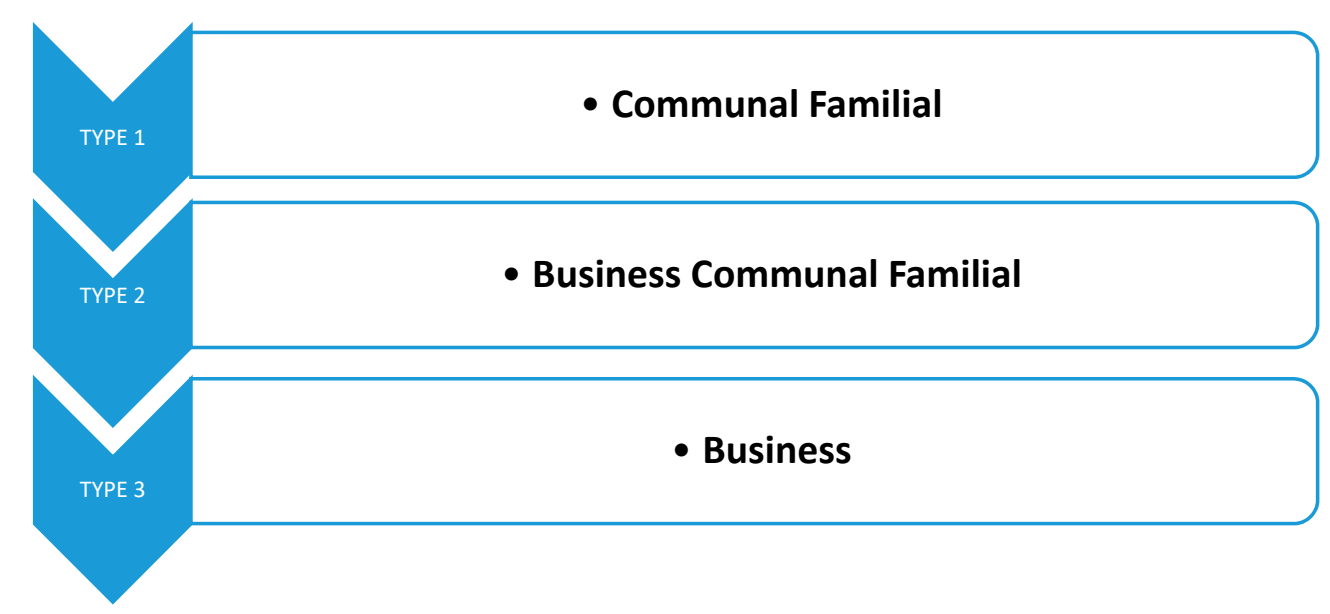

Figure 1. The development of familial business typology in kibbutz industry.

This diagram analyzes the development of familial business characteristics. Type 1 includes both privatized and non-privatized industries, kibbutz ownership and management and organizational prosperity. Type 2-an outcome of privatization instituted to stem organizational decline-comprises kibbutz-owned industries with outside top management. Type 3 results from privatization as well; in such cases, however, the crisis at each relevant industry was so severe that the respective kibbutzim had to sell their plants to private investors, who are responsible for their management.

\section{Summary and Conclusions}

The proposed typology identified three familial types that can be an example to other businesses, kibbutz and non-kibbutz enterprises:

1. Communal Familial Type: Kibbutz industries that are still communal, managed by members and enjoying economic prosperity, with all the communal cultural features typical of kibbutz enterprises (see Table 2).

2. Business Communal Familial Type: Kibbutz industries that suffered economic difficulties and underwent privatization but eventually retained ownership with the assistance of outside professionals, retaining only half the communal cultural features of Type 1 enterprises.

3. Business Type: Kibbutz industries that suffered severe financial crises and were sold to private investors, who introduced outside managers. Such businesses have no familial attributes or communal cultural features.

The first and second types can explain the sustainability of kibbutz industry over seventy years with the maintenance of its socialistic collective responsibility [3]. The second type emerged during the kibbutz crisis as a mixture of socialistic and capitalistic features that enabled adjustment to the new conditions. The third expresses only the factory's sustainability under conditions of extreme transformation, although severing communal contact may threaten the kibbutz community's sustainability, leading to the atrophy of this sociological phenomenon.

\subsection{Proposed Continuation of Research}

As the proposed typology is based on only five case studies, its development will require additional research for the accumulation of data from other kibbutz industries of various types. Questions to be examined include the following: Are all communal industries managed by kibbutz members? What type should be assigned to communal factories managed by outside professionals? How will 
privatized kibbutz industries in sound financial shape affect the familial business type? Are there similar types of communal business types that are not connected with kibbutzim?

\subsection{Managerial Implications}

1. A familial business type that recruits external workers can provide a more professional enterprise and reassure better sustainability for the firm.

2. Sustainability is best achieved by introducing small changes that can be assimilated into the traditional ethos.

3. A radical change from Type 1 to Type 3 can harm the community and threaten its sustainability.

Funding: Research grant from Zefat academic college.

Conflicts of Interest: The author declare no conflict of interest.

\section{References}

1. Palgi, M. Pitfalls of self-management in the kibbutz. Int. Rev. Sociol. 2006, 16, 63-77. [CrossRef]

2. Ben-Rafael, E.; Topel, M. Redefining the kibbutz. In The Kibbutz at One Hundred: A Century of Crises and Reinvention; Palgi, M., Reinharz, S., Eds.; Transaction Publishers: Piscataway Township, NJ, USA, 2011; pp. 249-258.

3. Moskovich, Y. Cultural features of a successful non-privatized kibbutz industry-lesson learned, an Israeli case study. Comp. Sociol. 2020, 19, 88-122. [CrossRef]

4. Olson, D.P.; Zuiker, V.S.; Danesa, S.M.; Stafford, K.; Heck, R.K.Z.; Duncan, K.A. The impact of the family and the business on family business sustainability. J. Bus. Ventur. 2003, 18, 639-666. [CrossRef]

5. Jaffe, D.T.; Lane, S.H. Sustaining a family dynasty: Key issues facing complex multigenerational businessand investment-owning families. Fam. Bus. Rev. 2004, 18, 81-98. [CrossRef]

6. Kleve, H.; Köllner, T.; von Schlippe, A.; Rüsen, T.A. The business family 3.0: Dynastic business families as families, organizations and networks-Outline of a theory extension. Syst. Res. Behav. Sci. 2020, 37, 516-526. [CrossRef]

7. Almaliach, T. Kibbutz Industries-1923-2007: Economic and Social Considerations; Yad Ya'ari: Givat Haviva, Israel, 2009.

8. Moskovich, Y.; Achouch, Y. From collectivism to capitalism: Cultural change in a kibbutz factory. J. Rural Coop. 2013, 41, 80-95.

9. Moskovich, Y.; Achouch, Y. Metamorphosis of a kibbutz industry: The life cycle of Millennium Industries—an Israeli case study. EuroMed J. Bus. 2015, 30, 181-197. [CrossRef]

10. Moskovich, Y.; Achouch, Y. Family home culture and management-employee relationships: Comparing two kibbutz factories. J. Co-Op. Organ. Manag. 2017, 5, 95-107. [CrossRef]

11. Nicholson, N. Evolutionary psychology, organizational culture, and the family firm: Academy of Management perspectives. Acad. Manag. 2008, 22, 73-84.

12. Chrisman, J.J.; Chua, J.H.; Sharma, P. Trends and directions in the development of a strategic management theory of the family firm. Entrep. Theory Pract. 2005, 25, 555-575. [CrossRef]

13. Kellermanns, F.W.; Eddleston, K.; Barnett, T.; Pearson, A. Family member characteristics and involvement: Effect on entrepreneurial behavior in the family firm. Fam. Bus. Rev. 2008, 21, 1-14. [CrossRef]

14. Zellwegera, T.M.; Eddleston, K.A.; Kellermanns, F.W. Exploring the concept of familiness: Introducing family firm identity. J. Fam. Bus. Strat. 2010, 1, 54-63. [CrossRef]

15. Pieper, T.M.; Klein, S.B.; Jaskiewicz, P. The impact of goal alignment on board existence and top management team composition: Evidence from family-influenced businesses. J. Small Bus. Manag. 2008, 46, 372-394. [CrossRef]

16. Salvato, C. Antecedents of Entrepreneurship in Three Types of Family Firms; Research Report 1/2002; Jönköping International Business School: Jönköping, Sweden, 2002.

17. Salvato, C.; Chirico, F.; Melin, L.; Seidl, D. Coupling family business research with organization studies: Interpretations, issues and insights. Organ. Stud. 2019, 39, 775-791. [CrossRef]

18. Carsten. J. After Kinship; Cambridge University Press: Cambridge, UK, 2004.

19. Malinowski, B. The Dynamics of Culture Change; Yale University Press: New Haven, CT, USA, 1945. 
20. Boon, J.A.; Schneider, D.M. Kinship vis-a-vis Myth Contrasts in Levi-Strauss' Approaches to Cross-Cultural Comparison. Am. Anthropol. New Ser. 1974, 76, 799-817. [CrossRef]

21. Dyer, W.G. Examining the "Family Effect" on Firm Performance. Fam. Bus. Rev. 2006, 19, 253-273. [CrossRef]

22. Kansikas, J.; Nemilentsev, M. Understanding family dynasty: Nurturing the corporate identity across generations. Int. J. Bus. Sci. Appl. Manag. 2010, 5, 31-42.

23. Ahrne, G.; Brunsson, N. Organization outside organizations: The significance of partial organizations. Organization 2016, 18, 83-104. [CrossRef]

24. Stewart, A.; Hitt, M.A. Why can't a family business be more like a nonfamily business? Modes of professionalization in family firms. Fam. Bus. Rev. 2012, 25, 1-29. [CrossRef]

25. Flamholtz, E.; Randle, Y. Growing pains: Transitioning from an Entrepreneurship to a Professionally Managed Firm; Jossey-Bass: San Francisco, CA, USA, 2007.

26. Yildirim-Öktem, Ö.; Üsdiken, B. Contingencies versus external pressure: Professionalization in boards of firms affiliated to family business groups in late-industrializing countries. Br. J. Manag. 2010, 21, 115-130. [CrossRef]

27. Bloom, N.; Van Reenen, J. Measuring and explaining management practices across firms and countries. Q. J. Econ. 2007, 122, 1351-1408. [CrossRef]

28. Chittoor, R.; Das, R. Professionalization of management and succession performance-A vital linkage. Fam. Bus. Rev. 2007, 20, 65-79. [CrossRef]

29. Hall, A.; Nordqvist, M. Professional management in family businesses: Toward an extended understanding. Fam. Bus. Rev. 2008, 21, 51-69. [CrossRef]

30. Dekker, J.C.; Lybaert, N.; Steijvers, T.; Depaire, B.; Mercken, P. Family Firm Types Based on the Professionalization Construct: Exploratory Research. Fam. Bus. Rev. 2012, 26, 81-99. [CrossRef]

31. Edmondson, A.C.; McManus, S.E. Methodological fit in management field research. Acad. Manag. Rev. 2007, 32, 1155-1179. [CrossRef]

32. Kim, F.; Mondello, M. Structural examination of managerial work values and constructive organizational culture: Use of the partial disaggregation method. J. Multidiscip. Res. 2014, 6, 5-14.

33. Fong, P.S.; Kwok, W.C. Organizational culture and knowledge management success at project and organizational levels in contracting firms. J. Constr. Eng. Manag. 2009, 135, 1348-1356. [CrossRef]

34. Gatfield, T.; Youseff, M. A critical examination of and reflection on the Chinese family business unit and the Chinese business clan. Fam. Bus. Rev. 2001, 14, 153-158. [CrossRef]

35. Igo, T.; Skitmore, M. Diagnosing the organizational culture of an Australian engineering consultancy using the competing values framework. Constr. Innov. 2006, 6, 121-139. [CrossRef]

36. Cameron, K.S.; Quinn, R.E. Diagnosing and Changing Organizational Culture Based on the Competing Values Framework; Addison-Wesley: New York, NY, USA, 1999; Jossey-Bass: Hoboken, NJ, USA, 2010.

37. Moskovich, Y. Belief systems and business kibbutz factory. J. Manag. Control 2018, 29, 5-36. [CrossRef]

38. Bate, S.P. Whatever happened to organizational anthropology? A review of the field of organizational ethnography and anthropological studies. Human Relat. 1997, 50, 1147-1175. [CrossRef]

39. Geertz, C. The Interpretation of Culture; Basic Books: New York, NY, USA, 1973.

40. Farias, C. Money is the root of all evil—or is it? Recreating culture through everyday neutralizing practices. Organ. Stud. 2017, 38, 775-793. [CrossRef]

41. Yin, R. Case Study Research Design and Method; Sage: London, UK, 2014.

42. Wadham, H.; Warren, R.C. Telling organizational tales: The extended case method in practice. Organ. Res. Methods 2014, 17, 5-22. [CrossRef]

43. Heracleous, L. An ethnographic study of culture in the context of organizational change. J. Appl. Behav. Sci. 2001, 37, 426-446. [CrossRef]

44. Aronson, J. A pragmatic view of thematic analysis. Qual. Rep. 1995, 2, 20-35.

45. Clark, L.S.; Heinrich, C.D.; Webber, S.A. Ethnographic interviews on the digital divide. New Media Soc. 2004, 6, 529-547. [CrossRef]

46. Spradley, J. The Ethnographic Interview; Holt, Rinehart \& Winston: New York, NY, USA, 1979.

47. Factory B. Dream and Practice: 40 Years of Factory B; Factory B: Kibbutz Nadiv, Israel, 2005.

48. T Industries. Sixty Years of T Industries; T Industries: Kibbutz, Israel, 2016.

49. Hammersley, M.; Atkinson, P. Ethnography: Principles in Practice, 2nd ed.; Routledge: London, UK, 1995. 
50. Strauss, A.; Corbin, J. Basics of Qualitative Research: Grounded Theory Procedures and Techniques; Sage: Thousand Oaks, CA, USA, 2015.

51. Moskovich, Y. Loss of organizational solidarity in three kibbutz factories. Int. J. Sociol. Soc. Policy 2016, 36, 624-635. [CrossRef]

52. Factory A. Farewell, Israel; Factory A: Kibbutz, Israel, 2008; p. 5.

53. Factory A. Action Plan-2009; Factory A: Kibbutz, Israel, 2009.

54. Factory A. Happy New Year; Factory A: Kibbutz, Israel, 2010; p. 6.

55. Factory A. Action Plan-2011-2013; Factory A: Kibbutz, Israel, 2010.

56. Factory A. CEO Musings_-2009; Factory A: Kibbutz, Israel, 2013.

57. Factory B. Factory B: \#6; Factory B: Kibbutz Nadiv, Israel, 2006.

58. Factory B. Factory B: \#12; Factory B: Kibbutz Nadiv, Israel, 2008.

59. Factory B. Factory B: \#12; Factory B: Kibbutz Nadiv, Israel, 2009.

60. Factory B. Factory B: \#12; Factory B: Kibbutz Nadiv, Israel, 2010.

61. Factory B. What Is Happening and What Will Happen; Factory B: Kibbutz Nadiv, Israel, 2012.

62. Factory B. What Is Happening and What Will Happen; Factory B: Kibbutz Nadiv, Israel, 2013.

63. Factory B. What Is Happening and What Will Happen; Factory B: Kibbutz Nadiv, Israel, 2014.

64. Factory B. What Is Happening and What Will Happen; Factory B: Kibbutz Nadiv, Israel, 2015.

65. Millennium Industries. CEO's Letter, 1 July 2007; Millennium Industries: Kibbutz Yahalom, Israel, 2007.

66. Millennium Industries. Income Statement, 31 December 2007; Millennium Industries: Kibbutz Yahalom, Israel, 2007.

67. Millennium Industries. Review of Goals, 26 December 2007; Millennium Industries: Kibbutz Yahalom, Israel, 2007.

68. Millennium Industries. Directorate Meeting Summary, 13 November 2008; Millennium Industries: Kibbutz Yahalom, Israel, 2008.

69. Millennium Industries. Directorate Meeting Summary, 29 January 2009; Millennium Industries: Kibbutz Yahalom, Israel, 2009.

70. Millennium Industries. Directorate Meeting Summary, 24 June 2009; Millennium Industries: Kibbutz Yahalom, Israel, 2009.

71. Factory C. Newsletter; Factory C: Kibbutz, Israel, 2009; Volume 81, pp. 15-20.

72. Factory C. Newsletter; Factory C: Kibbutz, Israel, 2010; Volume 84, pp. 1-2.

73. Edom, S.; Edur, R.; Kroll, Y. Motives, expectations and results of 2000-2009 M\&A privatization processes of the industrial activity of Israeli kibbutzim. J. Co-Op. Organ. Manag. 2015, 3, 85-93.

74. Talmon-Graber, Y. Kibbutz Family and Sleeping Arrangement of Children in Kibbutz; Haifa University Press: Haifa, Israel, 1991.

(C) 2020 by the author. Licensee MDPI, Basel, Switzerland. This article is an open access article distributed under the terms and conditions of the Creative Commons Attribution (CC BY) license (http://creativecommons.org/licenses/by/4.0/). 